\title{
МІЖДИСЦИПЛІНАРНИЙ ПІДХІД У ПРОФЕСІЙНІЙ ДІЯЛЬНОСТІ МАЙБУТНЬОГО ВИКЛАДАЧА ХУДОЖНЬО-МИСТЕЦЬКИХ ДИСЦИПЛІН
}

Окреслено шияхи розв'язання проблеми використання сучасних інформаційнокомунікаційних технологій на різних етапах художньо-творчої діяльності студентів. Предметна спеццифіка професійної діяльності майбутнього викладача художньо-мистеицьких дисцииплін дає можливість користуватися засобами сучасної комунікації на різних етапах виконання творчих проєктів, поєднуючи технічні засоби з новітніми освітніми технологіями. Висвітлено методичні особливості застосування IКТ під час пошуку інформацій, розробки проєкту, його оццінювання та самооцінювання. Запропоновано варіанти доцільного застосування загальнодоступних комп'ютерних програм $i$ засобів комунікації з метою підвищення професіоналізму виконання проєктів студентами, оптихізацій зворотного зв'язку між викладачем $і$ суб'єктами навчання, інноваційного підходу у виконанні комплексних завдань. Доведено, щцо навчання майбутніх викладачів художньо-мистецььких дисциилін єефективним на основі IКТ (мови програмування, готові програмні продукти, пакет програм Microsoft Office, хмарні сервіси, Інтернет-ресурси, WEB-сайт), упроваджених в освітній процес спеціальних і психолого-педагогічних дисциилін. Заняття з художньо-мистецььких дисциплін повинні бути яскравими, емоційними, із залученням великої кількості ілюстративного матеріалу, з використанням відеозаписів тощзо. Все цее може забезпечувати комп'ютерна техніка з ї мультимедійними можливостялии. Використання комп'ютера дае можливість побачити світ очима багатьох митців. Такі заняття виховують почуттл прекрасного, розиирюють кругозір здобувачів вищої освіти, дозволяють за обмежений час дати великий мистеиятвознавчий матеріал. Завдання впровадження IКТ полягае в тому, щзоб використання изих технологій стало звичайним і звичним у ділльності викладача та стало невід'ємною, органічною частиною будь-якого заняттяя.

Ключові слова: інформацзійно-комунікаційні технологї̈, проєктна діяльність, викладач художньо-мистецьких дисциплін, засоби комунікації, зворотній зв'язок.

Постановка проблеми. У статі розглянуто питання сучасної стратегї STEAM освіти, яка успішно розвивається в наш час, що $є$ результатом інтеграції науки і мистецтва, внаслідок якої народжуються наукові технології. Проаналізовано деякі історико-педагогічні аспекти цієї проблеми. Привернуто увагу до п'яти складників STEAM-освіти: S - science (природничі науки), T - technology (технологія), E - engineering (інженерне мистецтво), А - art (творчість) і M - mathematics (математика) та акцентовано на важливості мистецької складової в міждисциплінарному формуванні цілісної особистості. Висвітлено результати окремих досліджень вітчизняних та зарубіжних науковців. Проаналізовано підходи до впровадження таких норм освіти у США та Австрії, інших країнах Євросоюзу. Визначено, що для педагогічних представників, зокрема, майбутніх викладачів художньо-мистецьких дисциплін, упровадження STEAM допомагають підвищити власний рівень професіоналізму, покращити якість освітнього

*(C) Бойчук В. М.

*(C) Уманець B. O.

*C) ФуГуан

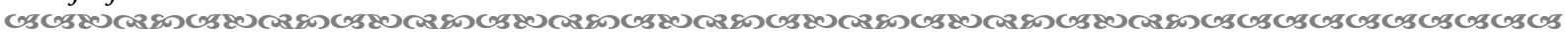


процесу, зменшити час підготовки до занять, дозволяе внести кардинально нове в роботу педагога. Художньо-творча діяльність $є$ важливим показником формування творчої особистості здобувача освіти, особливу роль у ставленні до образотворчої діяльності відіграє розвиток художнього сприйняття при ознайомлені 3 творами живопису, графіки, скульптури, декоративно-прикладного мистецтва. Це ознайомлення може мати різні форми, зокрема і з використанням сучасних інформаційних технологій та STEAM-підходів. Нами зроблено висновки, що всебічне розуміння наукових проблем, творчий та інженерний підхід до їх вирішення, критичне мислення, здатність обробляти дані, що репрезентують образні та символічні об'єкти; здатність аналізувати кілька потоків даних одночасно, інтегроване застосування наукових та художніх методів пізнання сприяє розвитку всіх важливих компетентностей майбутніх фахівців.

Міждисциплінарний підхід передбачає інтегративні зв'язки в освітньому процесі. Це зв'язки між навчальними дисциплінами різних галузей знань. Саме STEAM-освіта передбачає змішане (міждисциплінарне) освітнє середовище, в якому студенти, майбутні викладачі художньо-мистецьких дисциплін (далі - МВХМД) починають розуміти, як можна застосувати наукові методи на практиці, а з паралельним розвитком Arts-дисциплін формують і навички креативності. Реалії сучасної освіти вимагають регулярного перегляду узгодженості між підготовкою фахівців і вимогами до їх знань під час працевлаштування. Інноваційні технології в усіх галузях професійної діяльності людей відіграють важдиву роль і є підгрунтям економічного зростання. Більшість професій вимагають від фахівця знання комп'ютерної техніки і застосування різних іiі можливостей.

Професійна підготовка, яка формуе професійно-педагогічну компетентність МВХМД, вбирає історичні здобутки вітчизняної та світової тенденції. Теоретикометодологічний компонент системи професійно-педагогічної підготовки майбутніх фахівців художнього профілю зумовлюе зміни в цілях, меті, принципах, функціях, методиці професійно-художньої освіти, що гарантуе реалізацію у професійнопедагогічній діяльності їі потенціалу та спрямованість на поступове накопичення компонентів інноваційності студентів.

Під інноваційним розвитком ми розуміємо впровадження нововведень, необхідних для збільшення інноваційного потенціалу в професійно-педагогічній підготовці майбутніх фахівців художнього профілю. Ці інновації ефективно покращуватимуть результати професійної підготовки МВХМД в галузі художньоестетичного виховання, вдосконадюючи освітні, виховні та дидактичні аспекти педагогічної системи, стимудюючи впровадження високоефективних освітніх технологій. Впровадження інформаційно-комунікаційних технологій (IKT) в освітній процес у вищій школі, оцінювання його результатів та управління навчально-творчою діяльністю суттєво впливає на підвищення якості вищої освіти, прискорення соціальної і професійної адаптації майбутніх учителів трудового навчання та технологій.

Аналіз досліджень. Проблеми професійної підготовки педагогів розгдядади О. Абдуліна, В. Андрущенко, А. Алексюк, О. Дубасенюк, І. Зязюн, А. Ковальов, Н. Кузьміна, О. Пехота, В. Семиченко, С. Сисоєва, М. Скаткін, В. Чайка, В. Шахов, І. Якиманська та ін. Підготовку фахівців художнього профілю досліджували О. Музика, Л. Оршанський, О. Отич, Л. Сліпчишин, Р. Шмагало та ін. Проблеми художньопедагогічної підготовки викладачів мистецьких дисциплін розглядали Л. Бабенко, 1. Бичкова, В. Бойчук, І. Гдинська, Т. Завадська, М. Кириченко, С. Кондахчан, С. Коновець, Т. Люріна, Н. Миропольська, Б. Неменський, О. Олексюк, В. Орлов, Г. Падалка, М. Пічкур, О. Рудницька, О. Ростовський, С. Соломаха, О. Шевнюк, Г. Шевченко, В. Шульгіна, О. Щолокова, Б. Юсов та ін. Професійно-педагогічним аспектам художньої освіти присвятили свої праці Д. Богоявленська, В. Бутенко, В. Радкевич, В. Тименко та ін. Роль мистецьких факторів у сучасному освітньому процесі в контексті проблем STEAM-освіти розглядали М. Васильєв, В. Жукова, А. Жуманбаева,

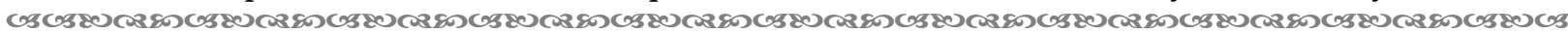
60 
А. Иманова, Е. Йоргенсен, О. Кухаревська, О. Матковська, Т. Перро, Р. Самуратова, А. Смирнов, Т. Стрельнікова, О. Шатунова та ін.

Метою статті є акцентування уваги на застосуванні інформаційнокомунікаційних технологій у діяльності МВХМД.

Виклад основного матеріалу. Одним із головних чинників підвищення ефективності професійної підготовки МВХМД є активне впровадження нових форм і методів навчання, зокрема загадьної комп'ютеризації освітнього процесу. Методичною основою професійної підготовки МВХМД вважаємо активне використання засобів, що розвивають творчі здібності здобувачів освіти та особистісні характеристики, формують уміння, необхідні для педагогічної діяльності, сприяють розширенню їх проєктної та дослідницької діяльності.

Освоєння IKT МВХМД реалізується за допомогою передбачених в освітній програмі нових предметів («Інженерна та комп'ютерна графіка»; «Конструювання засобами комп'ютерної графіки»), спрямованих на вивчення інформатики та IKT. Впровадження IKT у предметне середовище освітнього процесу передбачає інтеграцію різних предметних областей 3 інформатикою, що сприяе розумінню студентами процесів інформатизації в сучасному суспільстві (в його професійному аспекті) [3, с. 140].

STEAM-освіта $є$ результатом інтеграції науки і мистецтва, внаслідок якої народжуються наукові технології, запліднені морадьними цінностями. Союз фундаментального і гуманітарного знання дає могутній поштовх творчому розвитку особистості, активно розвиває креативний напрям освіти, що може вкдючати такі комплексні дисципліни, як промисловий дизайн, ландшафтну архітектуру, екологічну та індустріальну естетику тощо (Бойчук В. М., 2015, с. 290). STEAM сприяе розвитку таких важливих навичок, як комплексне розуміння наукових проблем, творчоінженерний підхід до їх розв'язання, критичне мислення, здатність до обробки інформації в образах і символах; здатність до аналізу декількох потоків інформації одночасно, інтегроване застосування наукового і художнього методів пізнання, використання в дослідницькій діяльності основ проєктування та ін. STEAM-освіта значною мірою сприяе «олюдненню» освітнього процесу, оскільки до сухих фактів, цифр та їх комбінацій ефективно підключає смисложиттєві цінності.

Інтерес до STEAM-освіти постійно зростає. Державні програми в царині STEAMосвіти прийняті урядами Австралії, Великобританії, Ізраїлю, Китаю, Кореї, Сінгапуру, США, Японії. Варто визнати, що найкращих результатів у впровадженні STEAM-освіти досягли Японія, Китай і Сінгапур. Це щотижневе вивчення значної кількості мистецьких дисциплін, міждисциплінарний підхід, цілеспрямоване навчання креативності та дизайну [3, с. 141].

Нині у педагогічній літературі все більша увага приділяеться методичним прийомам навчання, які розвивають творчу і пізнавальну активність здобувачів вищої освіти. «Мистецтво - особлива форма суспільної свідомості і дюдської діяльності, в якій художне (образне) пізнання життя органічно поєднується 3 науково-аналітичним процесом», - стверджуе Тьєррі де Дюв у своїй праці «Sewn in the sweatshops of Marx: Beuys, Warhol, Klein, Duchamp». Для успішного вирішення сучасних завдань естетичної освіти і розвитку творчості особистості використовуються нові технології в освітньому процесі, які роблять його більш результативним і відповідним вимогам сучасного життя. Ці технологї формують у МВХМД інтелектуальну, інформаційну, творчу і загальнокультурних компетентності.

Застосування інновацій неможливе без використання інформаційнокомунікаційних технологій, які вкдючають у себе підготовку і передачу інформації в освітньому процесі за допомогою інтерактивного устаткування. Вони забезпечують можливість забезпечити візуальне сприйняття інформації 3 теми заняття, дають можливість розглянути дрібні деталі й оцінити достоїнства мистецького твору,

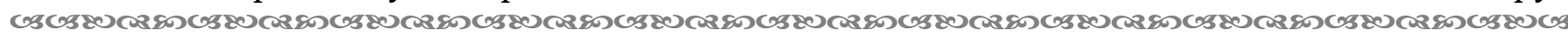


сприяють підвищенню мотивації та транспарентності заняття [2]. Все це доповнює інформацію, яку здобувачі освіти отримують під час проведення занять викладачем. Дия унаочнення важливими є різні фото і відеоматеріали, особистий досвід і враження педагога, а також позаурочна діяльність: організація виставок, зокрема, віртуальних, із використанням технологій 3D (рис. 1), відвідування театрів і концертів, пізнавальні екскурсійні поїздки у центри художніх ремесел і т.д.

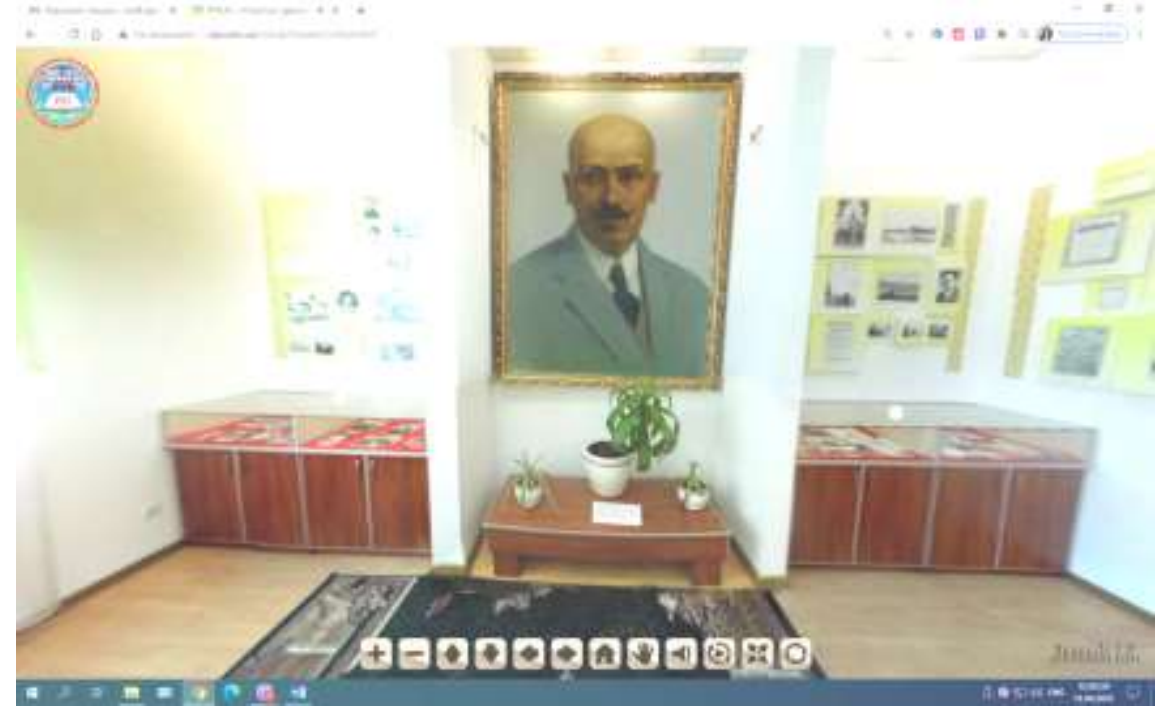

Рис. 1. Віртуальний тур: музей М.М.Коцююбинського Вінницзького державного педагогічного університету імені Михайла Коцюбинського [http://www.vspu.edu.ua/virtual/museum/virtual.html]

Сучасні здобувачі освіти активно користуються смартфонами, планшетами та стаціонарними комп'ютерами. Вони посідають важливе місце в їхньому житті, а для спілкування зі світом мистецтва у них залишається обмаль часу, відтак заняття з художньо-мистецьких дисциплін повинні заповнити недостатність знань у цій сфері та сприяти духовному розвитку МВХМД. За допомогою комп'ютерної техніки можна поєднувати теоретичний i демонстраційний матеріал. Здобувачі освіти можуть спробувати себе, наприклад, у ролі художника, дизайнера чи архітектора, що суттєво підвищує інтерес до творчості, сприяє кращому сприйняттю мистецтва і розширенню кругозору, допомагає формуванню відповідної компетентності [1, с. 33].

Застосування IKT розширило можливості використання та обробки зображень. Однак застосування спеціального програмного забезпечення для роботи 3 фотовідеографікою вимагає не тільки технологічних навичок, а й усвідомлення їхніх художніх можливостей [6, с. 200]. Нова технологія полегшуе отримання зображення, підвищуе його якість і в той же час змушуе по-новому поглянути на зміст зображення чи відеоряду як на мистецтво й інформаційне повідомлення одночасно. Цифрові технодогії сприяють розвитку в МВХМД інженерного мислення, підвищенню мотивації, відкривають нові мождивості створення творчих робіт з їх допомогою: колажі, фото і відео привітання, анімаційні фільми, 3D-моделювання i т.п. Сучасні електронні музичні інструменти та їх цифровізовані аналоги також надають МВХМД нові можливості. Адже «... частота музичних звуків і тембрових регістрів синтезаторів не фіксована жорстко, i виконавець може змінювати частоту і тембр плавними переходами», - зазначає Дюдмила Василевська-Скупа у своїй науковій розвідці «Метододогічний аспект підготовки майбутнього вчителя музичного мистецтва до розвитку співацького голосу учнів». 
При викладанні мистецтва очевидні такі переваги використання IKT: показ слайдів, відеофільмів, віртуальні подорожі найцікавішими містами і музеями світу, прослуховування музичних записів, демонстрація творчих робіт, використання знань, отриманих на заняттях із художньо-мистецьких дисциплін при підготовці до інших предметів гуманітарного циклу, що сприяе розвитку метапредметних зв' язків [5, с. 83].

Мистецька діяльність має важливе значення для всебічного розвитку особистості. У процесі створення, наприклад, зображення, формуються: спостережливість, естетичне сприйняття, художній смак, творчі здібності. Така діяльність надає мождивість доступними засобами висловити емоційний стан людини, ii ставлення до навколишнього світу, вміння самостійно створювати прекрасне, а також бачити його у творах мистецтва. Особливу роль у ставленні дюдини до мистецької діяльності відіграє розвиток художнього сприйняття при ознайомлені з творами живопису, графіки, скульптури, декоративно-прикладного мистецтва. Це ознайомлення може мати різні форми, зокрема і з використанням сучасних інформаційних технологій.

Під час спілкування 3 творами мистецтва створюються умови для всебічного овододіння можливостями художньої культури, виховується творча особистість. У художньо-естетичних цінностях людина знаходить джередо духовного збагачення, морального задоволення, співпереживання, соціального самоствердження, розвитку творчих сил й індивідуальних здібностей [3, с. 139]. Наприклад, можна навести такий історичний факт: під час політичних катакдізмів 20-го століття європейські мислителі розглядали конструкторські ігри не тільки як спосіб виховання дітей, а й як засіб зцілення їхніх душ (фактично, ідея STEM) (Наука искусства и искусство науки). Датський ландшафтний архітектор Карл Теодор Соренсен закдикав перетворити райони в містах, зруйнованих Другою світовою війною, у «сміттеві майданчики», де дітям роздадуть кирки, молотки, пилки і дозволять створити маленький новий світ (нагадує сучасну онлайн гру Minecraft). На цьому тлі ідея використовувати для навчання цю гру, що цілком складається 3 блоків, вже не здається такою реводюційною. Додаймо до цього вектор на STЕАМ-освіту (комплексний міждисциплінарний підхід 3 проєктним навчанням, що поєднуе в собі природничі науки 3 технологіями, інженерією і математикою та духовним розвитком). Для навчання була розроблена спеціальна версія - Minecraft: Education Edition (рис. 2).

Нині вона доступна для Windows 7, Windows 8.1, Windows 10, iOS i MacOS. E пробна версія, обмежена кількістю входів в систему (25 для вчителів та викладачів і 10 для здобувача освітнього рівня).

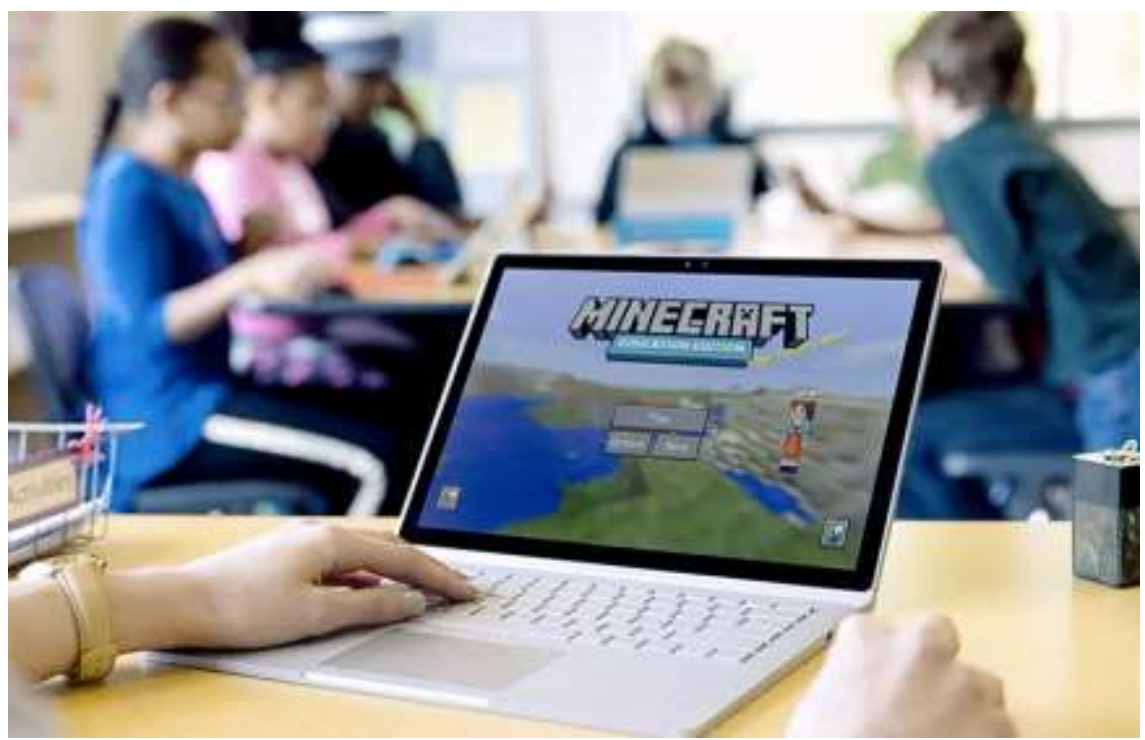

Puс. 2. Вікно входу в Minecraft: Education Edition 
Розробники (у контексті парадигми STEAM-освіти) у гру для освітніх установ додали такі інструменти, як камера і портфоліо. 3 їх допомогою здобувачі освіти роблять знімки, фіксують свій прогрес. Нововведення для викладачів створювалися з урахуванням реального досвіду педагогів, які використовували гру на своїх заняттях. Завдяки колегам-першопрохідцям з'явилися класні дошки для інструкцій і додаткових завдань, телепорт для швидкого переміщення по карті, мождивість відстежити місця розташування учасників освітньої гри, налаштування для коригування ушкоджень, циклу дня і ночі, складності гри і т. п. (Harvard Business Review, Digital Companies Need More Liberal Arts Majors).

Нині, у період світової пандемії, у реальному світі викладачі не можуть зібрати групу і провести очне заняття. I хоча Minecraft - віртуальний світ, МВХМД все одно змушенні замислюватися: «Що б я зробив у цій ситуації? Як побудувати фортецю на вершині гори і зміцнити їі? Як виростити і зібрати врожай зернових?». Усе це вони здатні зробити у грі, використовуючи як здобутті раніше знання 3 відповідних дисциплін, так і навички використання IKT, зокрема, ігрових технологій.

Якщо викладач готовий витратити трохи часу на те, щоб нахаштувати Minecraft і задати сценарії, потенціал занять стає нескінченним. Можна навчити МВХМД працювати в команді, давши завдання, виконання якого вимагає об'єднаних зусиль. Відпрацювати іншомовні комунікативні навички можна за умови спілкування під час гри лише іноземною мовою. При цьому зовсім не обов'язково бути експертом або палким фанатом гри. Щоб зацікавити здобувачів освіти, педагогові іноді досить відійти від ролі простого транслятора інформації.

«У Minecraft знання стають соціальною валютою», - стверджуе Майкл Дезуанні, доцент кафедри цифрових медіа в технологічному університеті Квінсленда (Австралія). Спочатку гра здається незбагненно складною, бо ні інструкцій, ні навчання не передбачено. У всьому потрібно розбиратися самому: читати форуми, дивитися відео на YouTube тощо. Мімі Іто, культурний антрополог з Каліфорнійського університету в Ірвіні (США), зазначає, що учасники такої освітньої гри, заглиблюючись у технічну складову, часто приходять за порадою на форуми і майданчики, де знайомдяться 3 дорослими гравцями: програмістами, дизайнерами, системними адміністраторами, і таким чином отримують уявлення про професійний шлях, який не завжди співпадає зі здобутими ними на иекціях чи семінарах знаннях та навичках [10].

Окрім того, використання такої методики гейміфікації освітнього процесу базуеться на ряді переваг Minecraft Education Edition. По-перше, Minecraft найпопулярніша гра в світі. Щомісяця в неї грають близько 112 мільйонів чоловік, конструктор практично є найкращим за результатами пошуку на YouTube за 2020 рік (відео, пов'язані з Minecraft'ом, подивилися більше ста мільярдів), а сайт Polygon взагалі визнав ऑï грою десятиліття. У Minecraft величезна фан-база, відтак серед здобувачів освіти, напевно, є ті, хто добре знайомий $з$ грою, тому зайвий раз правила пояснювати не доведеться.

По-друге, Minecraft дає простір для фантазї і майже не обмежує у можливостях. У ньому можна будувати, добувати ресурси, створювати і проходити квести, займатися спільною діяльністю або просто «бродити» віртуальним світом. Чим більше свободи, тим більше ідей, як іiі можна використовувати. У цій грі немає лінійної розповіді, але є бездіч інструментів для творчості, саме тому свобода та креативність гравця нічим не обмежена. Багато в чому саме це змушуе багатьох повертатися в Minecraft знову i знову.

Minecraft - це велика платформа, яка працює як ігровий «движок». Всередині гри можна створювати різноманітний контент, змінювати механіку предметів, додавати інтерактивні елементи. Це повноцінний GameDev: тут і левел-дизайн, і гейм-дизайн, і навіть саунд-дизайн. Тобто МВХМД під час використання Minecraft Education Edition формують та вдосконадюють за допомогою ігрових технологій компетенції, необхідні

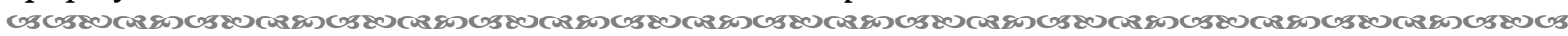


для вивчення дисциплін художнього циклу (Наука мистецтва і мистецтво науки). Наприклад, використовуючи технології Minecraft Education Edition, можна створити копію Мо́на Лізи (Джоконди) (італ. Mona Lisa, La Gioconda, фp. La Joconde) - картини, написаної італійським художником Леонардо да Вінчі). Результат представлено на рис. 3.

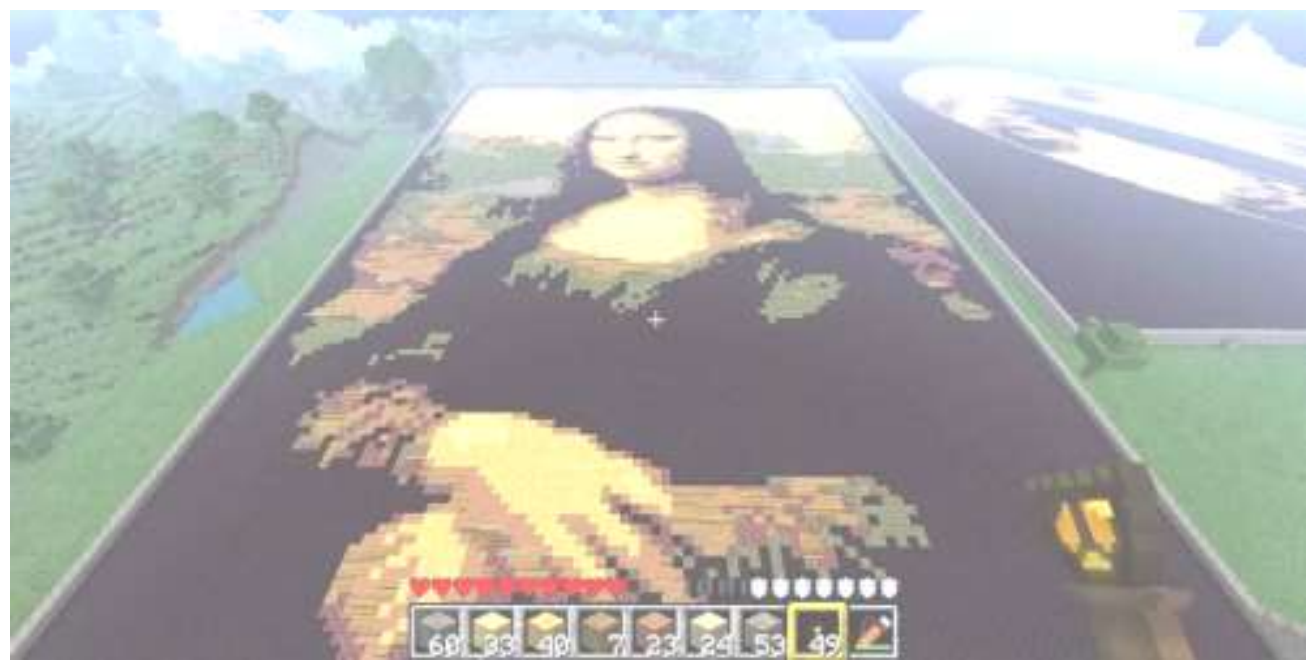

Pис. 3. Мона Аiза в релізі Minecraft Education Edition

Найбільш ефективними у структурі професійної освіти і в процесі вдосконалення професійно-педагогічної підготовки майбутніх педагогів-художників вважаємо дисципліни художнього циклу - «Рисунок», «Живопис» і «Композиція». Як базові дисципдіни вони адаптують студентів до творчого процесу, розвивають пізнавадьну здатність, формують готовність до свідомого використання зображень у творчій діяльності. ІКТ значно розширюють можливості подання змісту навчальної інформації. Застосування мультимедійної наочності, анімації, звуку, всіх сучасних засобів відеотехніки та інтерактивного спілкування (блоги, технологія ВікіВікі) дозволяе надавати інформацію швидше та в більш повному обсязі, сприяє кращому їі засвоєнню і запам' ятовуванню [8, с. 14].

Об'єднання компетентностей, здобутих МВХМД під час опанування базових дисциплін «Рисунок», «Живопис» i «Композиція» та дисциплін наступних циклів, таких, як «Комп'ютерна графіка», дає студентам мождивість набуття знань 3 графіки і видів графічного дизайну та опанування графічною мовою спілкування, передачею та збереженням інформації за допомогою різноманітних методів і способів іï відображення. Тому важливе місце серед змістових ліній навчального курсу відводиться загальним положенням теорії та практики графіки.

Чільне місце у змісті курсу посідає розділ «Закони зорового сприйняття графічної інформації, iï інтерпретації і «розкодування», а також вивчення та засвоєння МВХМД композиційних закономірностей i принципів побудови графічного зображення, що складає професійне підгрунтя діяльності майбутнього педагога. Особлива увага при вивченні цих дисциплін приділяється формуванню у студентів умінь використовувати сучасні методи проведення інтегрованих уроків образотворчого мистецтва та комп'ютерної графіки, а також логічних зв'язків з іншими дисциплінами, синтезу мистецтва і технологій, розвитку естетичного смаку та інформаційно-графічної культури школярів. Розробка студентами уроків образотворчого мистецтва за програмою інтегрованого курсу дозволяе сполучати традиційні та нові засоби і прийоми навчання образотворчому мистецтву у поєднанні з комп'ютерною графікою.

Використання IKT, ігрових технологій під час вивчення художньо-мистецьких дисциплін показало зацікавлення студентів наочним показом розроблених цифрових

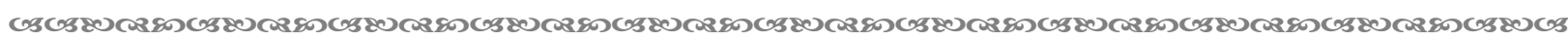


освітніх ресурсів як додаткового матеріалу при створенні власних дизайн-проєктів та презентацій [9, с. 116]. Аналізуючи презентації, зроблені під час практичних завдань, МВХМД мають можливість із фахових позицій оцінювати якісний дизайн, що є не меншим досягненням, ніж уміння його створювати. А набуття здобувачами освіти практичних навичок у роботі з мультимедійними засобами комп'ютерних технологій створюе професійне підгрунтя, що дозволяе в діяльності майбутнього педагога встановлювати оптимальні пропорції між комп'ютерним і традиційним навчанням образотворчого мистецтва і дизайну. Таким чином поєднання традиційних та інноваційних засобів навчання має ліквідувати шаблонність занять, зробити їх цікавими, а також забезпечити високий рівень навчального матеріалу. Аналізуючи можливості засобів IKT, необхідно наголосити на важливості розробки навчальних програм і методик формування інформаційно-художніх компетенцій МВХМД та ролі їх у розвитку творчої особистості.

Висновки. Завдяки впровадженню та поширенню інновацій у сфері освіти формується освітня система відкритого, гнучкого, індивідуалізованого, творчого знання. Ця система має поєднувати сучасні освітні технології, нові методи і прийоми викладання і навчання (педагогічні інновації) та нові засоби взаємодії у процесі освіти, тобто інформаційно-комунікаційні технології.

Інтегративні зв'язки в освітньому процесі - це зв'язки між навчальними дисциплінами різних галузей знань. Спроба активізувати освіту тільки в напрямі науки без паралельного розвитку Arts-дисциплін може призвести до того, що мододе покоління позбудеться навичок креативності. Впровадження закордонної новації STEAM-освіти - передбачає у вітчизняній практиці організацію змішаного (міждисциплінарного) освітнього середовища, в якому майбутні викладачі художньомистецьких дисциплін набувають досвіду практичного застосування наукових методів.

Таким чином, використання IКТ є невід'ємною частиною сучасного освітнього процесу. Методика правидьного застосування комп'ютерної техніки на заняттях є важливою ланкою у компетенції МВХМД. Але, як і будь-який засіб навчання, комп'ютер треба використовувати дозовано, виважено та не замінювати ним живе міжособистісне спілкування у процесі освіти.

Наше дослідження, звісно, не претендує на повне вирішення означеної проблеми. Зокрема, більшої уваги потребує глибоке дослідження критеріїв, форм, методів діагностики ефективності художньо-творчої діяльності та визначення ії впливу на рівень розвитку творчих та індивідуальних якостей особисті майбутнього викладача художньомистецьких дисциплін. Предметом подальших досліджень, на наш погляд, можуть стати пошуки нових форм організації художньо-творчої діяльності майбутніх викладачів художньо-мистецьких дисциплін у закладах вищої освіти.

\section{Список використаних джерел:}

1. Биков В. Ю. Інноваційний розвиток засобів і технологій систем відкритої освіти. Сучасні інформаційні технології та інноваційні методики навчання у підготовизі фахівців: методологія, теорія, досвід, проблеми: зб. наук. пр. Вінниця, 2012. Випуск 29, С. 32-37.

2. Биков В. Ю., Спірін О. М., Пінчук О. П. та ін. (2016). Інформаційно-аналітичні матеріали до парламентських слухань «Реформування галузі інформаційно-комунікаційних технологій та розвиток інформаційного простору України» - Інститут інформаційних технологій і засобів навчання НАПН України. 15 с. URL: http://lib.iitta.gov.ua

3. Бойчук В. М., Горбатюк Р. М., Кучер С. 1 . Методика застосування інформаційнокомунікаційних технологій у підготовці до проектної діяльності майбутніх учителів трудового навчання. Інформаційні технологїі і засоби навчання. 2019. № 3. С. 137-153.

4. Бойчук В. М. Теоретичні і методичні основи художньо-графічної підготовки майбутнього вчителя технологій: монографія. Вінниця: ФОП Рогальська, 2015. 564 с.

5. Бойчук В. М., Уманець В. О. Комп'ютерно орієнтовані технології у художній-графічній підготовці студентів педагогічних закладів вищої освіти напряму підготовки Професійна освіта. Інформаційні технологї̈ і засоби навчання. 2018. № 1, С. 81-94.

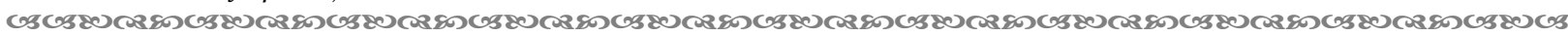
66 
6. Жук Ю. О. Теоретико-методичні засади організації навчальної діяльності старшокласників в умовах комп'ютерно орієнтованого середовища навчання: монографія. Київ: Педагогічна думка, 2017. 468 с.

7. Наука искусства и искусство науки. STEM URL: https://www.expocentr.ru/ru/events/stem-steam/

8. Уманець В. О., Гуревич Р. С., Кадемія М. Ю. Інноваційні технології у закладах вищої освіти. Сучасні інформаційні технологї та інноваційні методики навчання у підготовці фахівців: методологія, теорія, досвід, проблеми: зб. наук. пр. Київ; Вінниця, 2018. Випуск 51. С. 11-15.

9. Уманець В.О., Касянчук Н. В. Аналіз міжнародного досвіду при підготовці майбутніх фахівців з інформаційної безпеки. Відкрите освітне е-середовище сучасного університету: науковий журнал. Київ, 2019. Випуск 7. С. 110-118.

10. Vilorio D. STEM 101: Intro to tomorrow's jobs. URL: https://www.bls.gov/careeroutlook/2014/spring/art01.pdf.

11. Harvard Business Review, Digital Companies Need More Liberal Arts Majors. URL: //hbr.org/2016/01/digital-companies-need-more- liberal-arts-majors

\section{Referenses:}

1. Bykov, V. Yu. (2012). Innovatsiinyi rozvytok zasobiv i tekhnolohii system vidkrytoi osvity [Innovative development of tools and technologies of open education systems]. Suchasni informatsiini tekhnolohii ta innovatsiini metodyky navchannia u pidhotovtsi fakhivtsiv: metodolohiia, teoriia, dosvid, problemy, 29, 32-37 [in Ukrainian].

2. Bykov, V. Yu., Spirin, O. M., \& Pinchuk, O. P. (2016). Informatsiino-analitychni materialy do parlamentskykh slukhan «Reformuvannia haluzi informatsiino-komunikatsiinykh tekhnolohii ta rozvytok informatsiinoho prostoru Ukrainy» [Information and analytical materials for parliamentary hearings "Reforming the field of information and communication technologies and the development of the information space of Ukraine"]. Retrieved from http://ib.iitta.gov.ua [in Ukrainian].

3. Boichuk, V. M., Horbatiuk, R. M., \& Kucher, S. L. (2019). Metodyka zastosuvannia informatsiinokomunikatsiinykh tekhnolohii $u$ pidhotovtsi do proektnoi diialnosti maibutnikh uchyteliv trudovoho navchannia [Methods of using information and communication technologies in preparing for the project activities of future teachers of labour education]. Informatsiini tekhnolohii i zasoby navchannia, 3, 137-153 [in Ukrainian].

4. Boichuk, V. M. (2015). Teoretychni i metodychni osnovy khudozhno-hrafichnoi pidhotovky maibutnoho vchytelia tekhnolohii [Theoretical and methodological foundations of artistic and graphic training of future teachers of technology]. Vinnytsia: FOP Rohalska [in Ukrainian].

5. Boichuk, V. M., \& Umanets, V. O. (2018). Kompiuterno oriientovani tekhnolohii u khudozhniihrafichnii pidhotovtsi studentiv pedahohichnykh zakladiv vyshchoi osvity napriamu pidhotovky [Computer-oriented technologies in artistic and graphic training of students of pedagogical institutions of higher education in the direction of training]. Profesiina osvita. Informatsiini tekhnolohii i zasoby navchannia, 1, 81-94 [in Ukrainian].

6. Zhuk, Yu. O. (2017). Teoretyko-metodychni zasady orhanizatsii navchalnoi diialnosti starshoklasnykiv v umovakh kompiuterno oriientovanoho seredovyshcha navchannia [Theoretical and methodological principles of organizing the educational activities of high school students in a computer-based learning environment]. Kyiv: Pedahohichna dumka [in Ukrainian].

7. The science of art and the art of science. STEM vs STEAM. Retrieved from https://www.expocentr.ru/ru/events/stem-steam/[in Ukrainian].

8. Umanets, V. O., Hurevych, R. S., \& Kademiia, M. Yu. (2018). Innovatsiini tekhnolohii u zakladakh vyshchoi osvity [Innovative technologies in institutions of higher education]. Suchasni informatsiini tekhnolohii ta innovatsiini metodyky navchannia u pidhotovtsi fakhivtsiv: metodolohiia, teoriia, dosvid, problemy, 51, 11-15 [in Ukrainian].

9. Umanets, V. O., \& Kasianchuk, N. V. (2019). Analiz mizhnarodnoho dosvidu pry pidhotovtsi maibutnikh fakhivtsiv z informatsiinoi bezpeky [Analysis of international experience in training future specialists in information security]. Vidkryte osvitnie e-seredovyshche suchasnoho universytetu, 7, 110-118 [in Ukrainian].

10. Vilorio, D. (2014). STEM 101: Intro to tomorrow's jobs. Retrieved from https://www.bls.gov/careeroutlook/2014/spring/art01.pdf [in English].

11. Harvard Business Review, Digital Companies Need More Liberal Arts Majors. (2016). Retrieved from https://hbr.org/2016/01/digital-companies-need-more- liberal-arts-majors [in English]. 
Boychuk V. M., orcid.org/0000-0002-1082-3962

Umanets $V . O$. orcid.org/0000-0002-7237-4955

Fu Guan,

orcid.org/0000-0003-2025-9151

\section{USE OF INFORMATION AND COMMUNICATION TECHNOLOGIES AT DIFFERENT STAGES OF ARTISTIC AND CREATIVE ACTIVITY OF THE FUTURE TEACHER OF THE ART}

Ways to solve the problem of using modern information and communication technologies at different stages of artistic and creative activity of students are outlined. The subject specifics of the professional activity of the future teacher of art disciplines gives the opportunity to use the means of modern communication at different stages of creative projects, combining technical means with the latest educational technologies. The methodological features of ICT application during information retrieval, project development, its evaluation and self-evaluation are highlighted. Options for the appropriate use of public computer programs and means of communication to improve the professionalism of student projects, optimize the feedback between the teacher and the subjects, an innovative approach to complex tasks. It is proved that the training of future teachers of art disciplines is effective on the basis of ICT (programming languages, ready-made software products, Microsoft Office software package, cloud services, Internet resources, WEB-site), introduced into the educational process of special and psychological-pedagogical disciplines. Classes in art disciplines should be bright, emotional, with a lot of illustrative material, with the use of videos, and so on. All this can be provided by computer equipment with its multimedia capabilities. Using a computer makes it possible to see the world through the eyes of many artists. Such classes cultivate a sense of beauty, broaden the horizons of higher education, allow for a limited time to give a great art material. The task of ICT implementation is to make the use of these technologies common and habitual in the teacher's activities and become an integral, organic part of any lesson.

Key words: information and communication technologies, project activity, teacher of art disciplines, means of communication, feedback.

Дата надходження статті: 18.122020 p. Рецензент: доктор педагогічних наук, професор Заболотний В. Ф.

\section{УДК 378:355}

DOI https://doi.org/10.37915/pa.vi47.152

Іванченко Є. А., orcid.org/0000-0003-3071-0938

Пірко Ю. О., orcid.org/0000-0002-7147-9894

\section{МЕТОДИКА ОЦІНЮВАННЯ СФОРМОВАНОСТІ САМООСВІТНЬӦ̈ КОМПЕТЕНТНОСТІ МАЙБУТНЬОГО ВІЙСЬКОВОГО ІНЖЕНЕРА}

У статті розглянуто проблему створення методики оцінювання самоосвітньої компетентності майбутнього військового інженера. Дослідження попередніх авторів свідчать, що, по-перше, основою створення методики оцінювання самоосвітньої компетентності майбутнього фахівия є структура зазначеної якості, виходячи з якої визначаються критерії, показники та добираються методи діагностики; по-друге, самоосвітня компетентність

\footnotetext{
*(C) Іванченко $\Theta$. . A.
}

*(C) Пірко Ю. О.

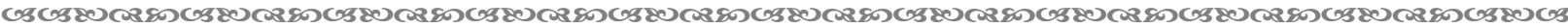

